of the last tooth and part of the arrangement for pushing it up into a working position in the absence of pressure from behind. Mr. Adams (loc. cit., p. 1 describing a much detrited last lower molar in the Woodwardian useum, says: "The fangs had become consolidated into a ridge like the keel of a vessel "-an exactly similar condition to that here displayed. This character may thus be taken as confirming the conclusion otherwise arrived at that this is an ultimate molar. For a microscopis examination of the substance of the keel the writer is indebted to Mr. W. Courtney Iyne, who identifies it as dentine, which normally composes the fangs.

Compared with last lower molars of the mammoth described by Mr. Adams (loc. cit.), and with the fragments in the Birmingham Vniversity Geological Museum, this is rather a narrow tooth, but the measures of several narrower are given in the work referred to. On the other hand, judging by what remains, it would, when complete, be fully as long as the complete molars there described, but these from their very completeness are probably for the most part smaller than the average. It is, indeed, by no means as large in any dimension as they often attain.

The tooth is in a good state of preservation, the grinding surface, though much cracked, preserving the original relief and a fair degree of polish on the enamel. But at the sides of the crown the cement has in places fallen away as has also dentine from the keel. It exhibits no effects of water-wear and so cannot have been carried by water far from the mandible and the skull. There is every probability, therefore, of more mammoth remains having been entombed in the neighbouring gravel.

The tooth is in the possession of Mr. Harrison's widow, to whom the writer is deeply indebted for an extended loan of the specimen and for information regarding the position of the find.

EXPLANATION OF PLATE $X$.

Photegraph of ultimate right lower Molar of Mammoth found at North Wocdchester, near Stroud, by the late Mr. W. Harrison, of Selly Oak, Birmingham, Easter, 1916. Photo-half natural size.

\title{
The Primary Zones of Cornish Lodes
}

By E. H. Darison, B.Sc., F.G.S.

D URING the last two and a half years I have been engaged in the study of the Cornish Veinstones in the field and in the laboratory by microscopic and other methods, and have come to the following conolusions:--

That, as recognized by many observers, the primary minerals of Cornish lodes occur in zones which change their character in depth ; thus copper minerals give place to cassiterite on passing down the lode and chlorite gives place to tourmaline.

From observations on over 150 lodes in more than 100 different mines, taken on the spot or abstracted from old records, in and 
around the Carn Menellis granite mass, from Camborne and Redruth on the north to Falmouth and Helston on the south, it appears that the boundaries of the various zones can be determined within reasonable limits. I felt some hesitation at trusting to old records of depth which were sometimes measured on the underlie of the lode and sometimes vertically, but on determining the average depth below surface at which predominant copper gives place to copper with tin, from old and recent records, in the neighbouring parishes of Redruth and Camborne taken separately (the two areas having a similar geological character). I found that the two results differed by less than 15 fathoms, which shows that the estimates were sufficiently accurate to justify the conclusions drawn.

The general character of the zoning as regards tin and copper has been described by MacAlister, ${ }^{1}$ but wolfram and arsenic are also to be considered, as they are important Jode constituents. The general occurrence of the minerals is as follows :--

1. A zone situated some distance above the granite surface in the clay slate and often extending beyond the metamorphic aureole in which the metals silver, lead, and zinc are predominant. These metals arrived later than the tin or copper and often filled fissures belonging to a later period of earth movement, but they are also occasionally found in the uppermost parts of the tin-copper lodes, and this was probably still more often the case before the lodes were so extensively planed down by denudation.

2. A zone in which copper is the predominant metal comes next below the silver-lead zone. The copper zone passes downwards into the next zone at a depth which depends on the level of the granite surface.

In the neighbourhood of ridges or of "cupolas" on the granite surface the place of copper is usually taken by wolfram, and there is then a wolfram zone just above or just inside the surface of the granite mass.

3. A zone characterized by the occurrence of both tin and copper in fair proportions. In the proximity of "cupolas", or ridges, this zone becomes in many instances a tin-wolfram zone.

4. A zone in which cassiterite is the predominant metallic mineral.

In no mine has the lower limit of this tin zone been actually reached, but evidence obtained in the mines sunk most deeply in the granite seems to indicate that there is a limit to its extension downwards. If the cassiterite does not actually dic out, its grain tends to become so fine as to render profitable exploitation very difficult.

In the following notes on the various zones the general characters of the veinstones bave been kept in view throughout; local exceptions occur, but only in a few instances.

1 Geological Surcey Memoir, Sheet 352, Camborne and Falmouth, 1906. 


\section{The Silver-Lead Zone.}

The number of instances in which tin- or copper-bearing lodes pass upwards into lodes carrying lead and silver is too small to admit of any generalization. Silver and lead occurred with tin and copper in the Engine Iode, South Tresavean, silver with arsenic in the South Entral Tode, Dolcoath, and horn silver in the lode at North Dolcoath. Most of the lead-silver lodes have a north and sonth direction, and are of distinctly later date than the tin-copper lodes.

\section{The Copper Zoxe.}

This zone is characterized by the predominance of copper minerals with mispickel as a frequently associated mineral. The copper orcurs mainly as chalcopyrite, which seems to be the only original sulphide, the others present, such as hornite, erubescite, cuprite, native copper, and the oxidized compounds having been formed by its secondary alteration. Pyrite and some of the mispickel seem also to be of secondary origin.

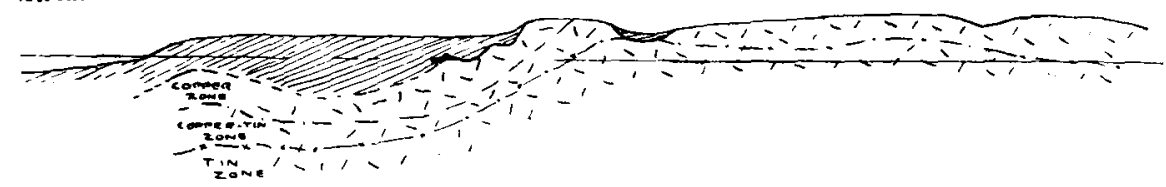

FI;. 1.-Sketch section to show relation of zones to granite surface.

The chief gangue minerals are quartz, chlorite, fluorspar, and muscovite; tourmaline is not usually an important component, but occurs locally in one or two districts.

The copper zone is in nearly every case restricted to the clay slate; its lower limit in the Camborne-Redruth district lies at an average depth of 100 fathoms, with a maximum of about 200 fathoms. As it is traced northwards away from the Carn Menellis granite mass, the base of the zone falls steadily (Fig. 1).

The position of the zone in other districts can be seen from the following table :-

\begin{tabular}{|c|c|c|c|c|}
\hline \multicolumn{3}{|c|}{ Distrirt. } & $\begin{array}{c}\text { Depth of Base of Copper } \\
\text { Zone in fathoms. } \\
\text { Lerage. Maximum. }\end{array}$ & $\begin{array}{c}\text { Pasition of area, relative } \\
\text { to granite. }\end{array}$ \\
\hline Camborne & and & Redruth & $100: \quad 200$ & On flank of granite mass. \\
\hline Gwennap & . & . $\quad$. & $150 \quad$ plus 300 & Away from granite mass. \\
\hline Wendron & . & . & No Copper Zone. & Heart of granite mass. \\
\hline Crowan & . & & 50 & Flank of granite inass. \\
\hline Grwinear & & . & 150 & $\begin{array}{l}\text { Away from granite mass } \\
\text { but in area of contact } \\
\text { altered slate. }\end{array}$ \\
\hline St. Day & . & • & 60 & Flank of granite mass. \\
\hline
\end{tabular}




\section{E. H. Davison-Primary Zones of Comish Lodes.}

The close connexion between the predominance of copper and the granite is shown by instarces of lodes passing from slate to granite into slate again, the copper always being predominant in the slate and the tin in the granite.

\section{The Wolfram ZoNe.}

As mentioned above, the place of copper is sometimes taken by wolfram, which occupies a similar relative position in the lode. It is probably not accidental that all the wolfram-producing lodes are found in the neighbourhood of ridges or minor domes ("cupolas") of the granite. In such position the wolfram may be found either in the clay slate, as at Castle-an-Dinas and Killifreth, or just inside the granite, as at Hemerdon and Kit Hill. It may also occur in lodes passing from the slate into the granite, as in the case at Tin Croft Mine, Roger's Lode, East Pool Mine, etc. The lodes are of coarser texture than usual, and sometimes show a pegmatite-like structure, the chief minerals being quartz, chlorite, mispickel, wolfram, and cassiterite; tourmaline is not usnally present in large quantities, fluorspar is often present, and molybdenite, stannine, and pyrite are occasional constituents. The wolfram content decreases and the cassiterite increases as the lode is followed from the slate into the granite either in depth or horizontally.

\section{The Copper-Tis ZoNF.}

In most cases the copper zone of a lode passes downwards into a zone in which the lode carries both copper and tin in fair proportions. This zone is perhaps more correctly described as a passage zone from the zone of predominant copper to that of predominant tin, but it is often so clearly marked and has produced so much ore in many mines, that its classification as a separate zone is perhaps justified.

In the various districts the position of the zone is as follows:--

\begin{tabular}{|c|c|c|c|c|c|}
\hline \multicolumn{3}{|c|}{ District. } & \multicolumn{2}{|c|}{$\begin{array}{c}\text { Depth of Base of Cu Sn } \\
\text { zones in Fathoms. } \\
\text { Average. Maximum. }\end{array}$} & Position of Area. \\
\hline Camborne & and & Redrut! & 180 & 300 & On flank of granite mass. \\
\hline Gwennap & . &.$\quad$. & $-\ldots$ & $\therefore$ & Away from granite mass. \\
\hline Wendron & . & . & 50 & 100 & Heart of granite mass. \\
\hline Crowan & . & . & 150 & $\cdots$ & Flank of granite mass. \\
\hline Gwinear & . & . & 200 & - & $\begin{array}{l}\text { In area of contact altered } \\
\text { slate away from granite. }\end{array}$ \\
\hline St. Day & - & . & 150 & - & Flank of granite mass. \\
\hline
\end{tabular}

The composition of the lode-stuff is similar to that of the copperzone, but mispickel is more common, and tourmaline is present in greater proportion. The veinstone generally appears under the microscope as well-crystallized, with quartz, chlorite, mica, tourmaline in well-formed blue and brown prisms, chalcopyrite, 
mispickel, and cassiterite in large, well-formed crystals. The chalcopyrite and mispickel are seen to have crystallized after the cassiterite, which is often included in them. This type of veinstone is often a bright green colour in the hand specimen, and with a vughy texture; it is locally termed "peach". The number of lodes which pass downwards from a zone with predominant wolfram is small, as few wolfram lodes have been worked to any depth. The facts show, however, that wolfram dies out and cassiterite increases as the lode is followed into the granite and there is possibly a similar passage zone to that of the copper-tin lodes.

\section{The Tin Zoxe.}

In all the lodes the tendency is for the lode to become predominantly tin-bearing in depth. There is also a decided change in the character of the veinstones. The chlorite, so common a constituent in the upper zones, diminishes or disappears, and the type of veinstone locally termed "capel" is the usual one. This is a fine-grained blue veinstone composed of quartz crowded with microscopic needles of blue tourmaline, and often brecciated, the fragments consisting of capel containing fragments of cassiterite, and clear quartz, the cement being quartz, coarser tourmaline, and cassiterite which is more coarsely crystallized and of a paler colour than that in the capel.

There are only a few mines which have been worked to any great depth in the granite, and in consequence the facts on which con. clusions might be based are scanty. There seems, however, to be a distinct indication that there is a limit in depth to the tin zone. In many instances the cassiterite not only decreases in amount, but, also becomes af a decidedly finer grain, thus rendering the lodestuff less amenable to concentration by gravitational methods.

In reference to the fine grain of the cassiterite in some veinstones, both at moderate and considerable depths in the granite, I would refer to my paper read before the Royal Geological Society of Cornwall, ${ }^{1}$ in which cassiterite is described as occurring in the form of minute inclusions in quartz, the grains being less than one micromillimetre in diameter.

The extent of the zones described above varies very greatly at different points round the granite mass, and this variation has been attributed ${ }^{2}$ to the variation in slope of the granite surface below the slate. Recent development of the mines has produced fresh evidence of the fact that the Carn Menellis mass slopes very gradually to the north below the clay-slate (Figs. 2, 3, and 4). The occurrence of a large inclusion of granite in the quartz-porphyry ("elvan ") dyke at Bridge, near Portreath, suggests that even so

\footnotetext{
1 "On the Mode of Occurrence of Cassiterite in Cornish Veinstones, etc." : Proc. Roy. Geol. Soc. Corn., 1919.

${ }^{2}$ MacAlister, Geol. Surv. Mem. Sheet 352, Camborne and Falmouth, 1906.
} 
far to the north as that the granite is at no great distance below the surface, and there is every probability that the copper and tin zoines occur at workable depths over a large area to the north of the present mines in the Camborne-Redruth district.

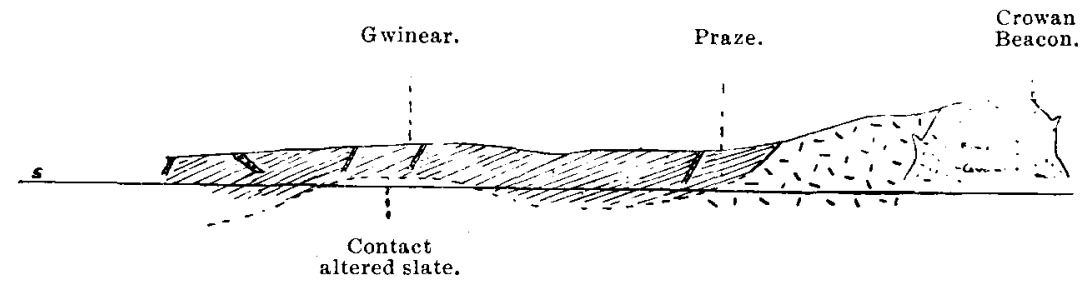

FIG. 2.-Sketch section from Crowan Beacon to Gwinear.

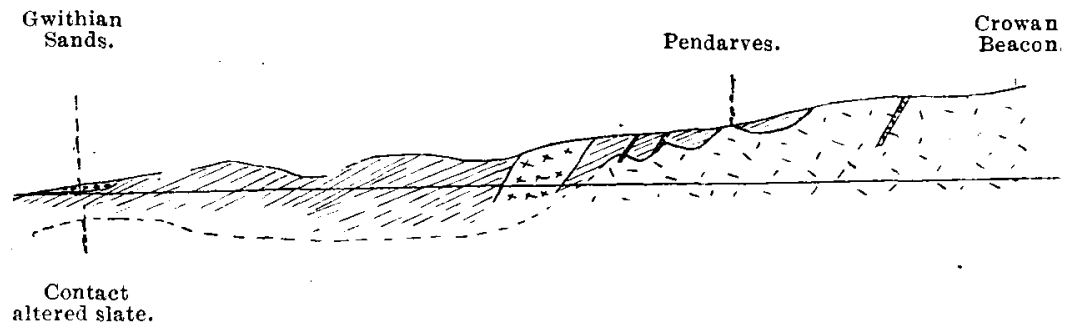

FIg. 3, - Sketch section from Crowan Beacon to Gwithian.

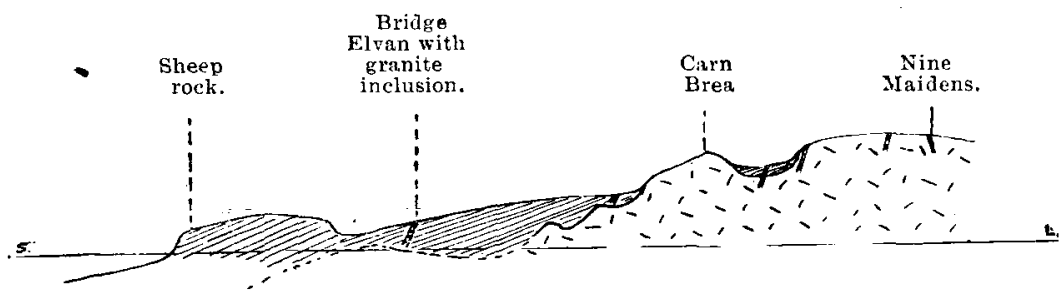

FIG. 4.-Sketeh section from Nine Maidens to Portreath.

In addition to the vertical zones of the lodes described above, there is a variation in the lode contents along the strike. A lode is not usually of uniform value throughout its length, but the metallic minerals occur in "shoots" or "courses" which alternate along the lode with areas of low-grade ore of little or no economis value. These shoots are not usually vertical, but run diagonally down the lode and their exact relationship to their surroundings remains to be determined. It seems probable that they are due to variation in the country rock, and in the nature of the fissure, and I am at present engaged in the collection of data concerning them. 


\section{The Order of Arrival of the Minerals.}

The detailed microscopic study of the veinstones has shown that the order of arrival of the ninerals is not always the same. As a general rule the order, as shown by the relations of the constituent minerals, is :-

1. Quartz, mica, tourmaline, topaz, cassiterite, wolfram, stanuine, and molybdenite.

2. Quartz, chlorite, fluor, chalcopyrite, mispickel, pyrite, and blende.

3. Lead and silver ores.

4. Secondary minerals such as other sulphides of copper, scheelite, carbonates, etc.

Wolfram is often earlier than cassiterite, and the latter is usually before tourmaline. Chalcopyrite is often before mispicke!, and pyrite is usually later than both.

\section{Veinstones of Unusual Characters.}

In many instances the close relationship between igneous intrusion and lode formation is easily seen. The veins at Hemerdon, ${ }^{1}$ Kit Hill, St. Michael's Mount, and Cligga Head are, as a rule, veins of greisen or pegmatite in the granite. ${ }^{2}$ In other cases veinstones occur which have all the characters of pegmatites so far as texture and simultaneous crystallization are concerned. Such is the vein seen in the stope between the 148 and 160 levels, New Cook's Section, South Crofty, which shows large porphyritic crystals of wolfram, interlocked with coarsely crystalline quartz, mispickel, stannine, and chlorite, the minerals having crystallized at or about the same time. In Tin Croft Mine, again, there occurs a veinstone composed of quartz, altered felspar, chlorite, wolfram, and mispickel, with smaller proportions of cassiterite and fluorspar, in which the quartz wolfram and felspar penetrate one another.

Another occurrence of interest in this connexion is that of the pegmatite near the bottom of Dolcoath New Shaft, in which cassiterite occurred associated with garnet.

The association of cassiterite with acid intrusives is also shown by its frequent occurrence as a constituent of quartz-porphyry dykes ("elvans"). The occurrence at Parbola Mine is well-known, and microscopic examination has shown it to occur in many of the quartzporphyry dykes of the Carn Menellis area. ${ }^{3}$

This constant connexion between the occurrence of the cassiterite with the products of the residual magma confirms the generally accepted idea that, by whatever means it was carried to and deposited in the lodes, the source of the metal was the granite magma.

\footnotetext{
1 "On the Characters of some Cornish Veinstones": Proc. Cornish Inst. of Engineers, 1920.

"2 "On the Geology of St. Michael's Mount": Proc. Roy. Geol. Soc. Corn., 1920 .

3 " On the Mode of Occurrence of Cassiterite, etc." : Proc. Roy. Geol. Soc., Corn., 1919.
} 
Evidence bearing on the Deposition of Cassiterite.

The structure of an alluvial pebble of cassiterite found in the Nanpusker Valley throws some light on the manner in which the mineral was deposited. The pebble consists of a roughly hemispherical nodule of cassiterite about half an inch in diameter with white quartz attached; through this quartz rays of cassiterite needles run radiately from the main mass. Microscopic exmination shows that the cassiterite nodule is crystalline dark brown in colour and beautifully zoned. The rays consist of two kinds. Nearest to the nodule there are bunches of dark brown cassiterite needles, and further away there is a zone of yellow prisms of cassiterite with good crystal outlines, while outside these the quartz is crowded with small needles and skeleton crystals. The quartz is seen to be a mosaic of small irregularly shaped grains, which are in optical continuity around the ends of the cassiterite crystals and needles. The structure shows that the cassiterite either crystallized contemporaneously with the quartz or that crystallization took place in a silica jelly sufficiently viscous to hold the needles in position.

In conclusion, I must express my thanks to Mr. Harvey Kitto for collecting information with regard to Killifreth Mine, to Tehidy Minerals Company, Limited, for permission to inspect their plans and sections, and to the managers of the various mines visited for giving me valuable information and every facility for carrying out the work.

\section{Platinum-bearing Rocks in the Lizard District.}

By G. McPherson, jun., Stud.I.M.M., and T. Lamb, Stud.I.M.M. CÒME remarks made at a meeting of the Cornish Institute of D Engineers by Dr. R. H. Rastall directed attention to the possibility of platinum being found in the Lizard. In a paper upon "Ore Deposits of Igneous Orioin", Dr. Rastall pointed out that in the Lizard the local characteristics were favourable to the presence of platinum, although no definite information of its occurrence had been reported. Much interest was aroused locally by these remarks, and the writers resolved to investigate the alluvials derived from the altered ultrabasic igneous rocks of the Lizard Group.

The main rock features of the Peninsula may be shortly indicated as follows. Against the Ordovician and Devonian schists of Cornwall lies the Lizard Group of greatly altered igneous and sedimentary rocks of the Basement Complex, separated from the schists by the Iizard fault and a much brecciated belt which traverses the Peninsula from east to west. The Lizard Group may be briefly described as consisting of mica- and hornblende-schists successively intruded by ultrabasic, basic, and acid bosses and dykes, all much altered by regional metamorphism. Minor intrusions are common, and frequently along the borders of the larger masses mixed rocks 